\title{
The degradation of kraft lignin during hydrothermal treatment for phenolics
}

\author{
Kai Tang ${ }^{1}$, Xue-Fei Zhou ${ }^{1,2,3,4,5, ~ 6, ~ 7, ~} 8^{*}$ \\ ${ }^{1}$ Sichuan University of Science and Engineering, Material and Chemical Engineering Institute, Zigong, 643000, China \\ ${ }^{2}$ Nanjing Forestry University, Jiangsu Provincial Key Laboratory of Pulp and Paper Science and Technology, Nanjing, \\ 210037, China \\ ${ }^{3}$ Kunming University of Science and Technology, P.O. Box A302-12, Building No.5, XinyingYuan, No.50, Huancheng East \\ Road, Kunming, 650051, China (Corresponding affiliation) \\ ${ }^{4}$ Guangxi University, Guangxi Key Laboratory of Petrochemical Resource Processing and Process Intensification Techno- \\ logy, Nanning, 530004, China. \\ ${ }^{5}$ Sichuan University of Science and Engineering, Key Laboratory of Green Chemistry of Sichuan Institutes of Higher \\ Education, Zigong, 643000, China. \\ ${ }^{6}$ Huaiyin Normal University, Jiangsu Key Laboratory for Biomass-based Energy and Enzyme Technology, Huaian, 223300, \\ China \\ ${ }^{7}$ Tianjin University of Science and Technology, Tianjin Key Laboratory of Pulp and Paper, Tianjin, 300457, China. \\ ${ }^{8}$ State Key Laboratory of New Ceramics and Fine Processing of Tsinghua University, Beijing, 100084, China \\ "Corresponding author: e-mail: lgdx602@tom.com
}

\begin{abstract}
Kraft lignin was hydrothermally depolymerized at low temperature/short time in water for producing value-added phenolics. The effects of residence time $(15,60 \mathrm{~min})$ and reaction temperature $\left(130,180,230^{\circ} \mathrm{C}\right)$ on yields of oils and phenolic compounds were studied in detail. Total oil yield was found to range between $7 \%$ and $10 \%$. The compositions of oils were analyzed by GC-MS to confirm the main compound to be guaiacol (2-methoxy phenol) in the range of $12-55 \%$ of oil depending on different reaction conditions. The most interesting was the finding that maximum value of total oil yield (10\% of kraft lignin) and guaiacol amount (55\% of oil) was obtained at $130^{\circ} \mathrm{C} / 15,60 \mathrm{~min}$ which is a low reaction temperature/short time, while the residual kraft lignins were analyzed by FTIR with respect to the conversion mechanism of kraft lignin by this process.
\end{abstract}

Keywords: kraft lignin, hydrothermal treatment, low reaction temperature/short time, oil, phenolics.

\section{INTRODUCTION}

Lignin is by far the most abundant substance based on aromatic moieties in nature components; its complex aromatic structure is highly dependent on the natural source and on the process used for its extraction and/ or separation. Lignin is formed by different monomers as well as different functional groups depending on the source in nature ${ }^{1}$. As aromatic compound lignin is used either directly or chemically modified, as a binder, dispersant agent for pesticides, emulsifier, heavy metal sequestrant, or component for composites and copolymers. At the same time due to the extreme complexity of lignin, new conversion technologies must be developed for value-added applications of lignin, especially for the preparation of low molecular weight compounds as an alternative to the petrochemical industry ${ }^{2,3}$.

Thermochemical processes are widely used in biomass conversion for fuels and chemicals. These conversion processes include three sub-categories: gasification $\left(>600^{\circ} \mathrm{C}\right)$, pyrolysis $\left(370-530^{\circ} \mathrm{C}, 0.1-0.5 \mathrm{MPa}\right)$ and liquefaction $\left(230-330^{\circ} \mathrm{C}, 5-20 \mathrm{MPa}\right)^{4}$. A number of studies have detailed with the thermochemical pathways that can be used for converting lignin into more valuable products. Catalytic or non catalytic and a large range of processes from fast pyrolysis to hydrothermal or solvothermal methods or hydroconversion have been reported on the conversion of lignin and lignin model compounds. The principal thermochemical routes applied to lignin depolymerization include cracking or hydrogenolysis and hydrodeoxygenation and various catalyses. All the proposed pathways have their own advantages and drawbacks besides any economical considerations $\mathrm{s}^{5-8}$. Moreover, hydrothermal process has become an important process in the chemical conversion of biomass as water is a unique, and environmentally benign solvent ${ }^{9,10}$, it remains a challenging task to hydrothermaly convert kraft lignin under low temperature/short time.

Compared with other lignin degradation methods, the hydrothermal treatment has some excelent properties: (1) an absolute cost advantage due to unnecessary predrying of lignin, (2) no further treatment of nitrogen oxides and sulfur oxides produced from $\mathrm{N}$ and $\mathrm{S}$ elements in lignin due to dissolving of these oxides in water under hydrothermal conditions, (3) a hydrogen source from water in hydrothermal conditions, and (4) relative low operating conditions due to the existence of hydrolysis reaction ${ }^{11-13}$. On the other hand, kraft lignin is usually a co-product of kraft pulping, while the predominant pulping process is likely to produce the most available source of lignin ${ }^{14,15}$. Based on its phenolic functionalities and properties, kraft lignin offers possibilities for hydrothermal treatment for some increasing applications in addition to the ones coming from the pulp industry.

In this work, kraft lignin was depolymerized in water under low-temperature hydrothermal conditions to produce phenolics. The composition of the resulting products was identified by GC-MS and the molecular weight of oils was analyzed by GPC. Effects of reaction temperature and reaction time on the yield and the composition of products were explored. In addition, chemical information of residual kraft lignin was examined by FTIR to further understand the conversion mechanism of kraft lignin.

\section{EXPERIMENTAL}

\section{Material}

All starting materials described herein were commercially purchased from Sinopharm Chemical Reagent Co. 
Shanghai (China) and used as received without further purification, unless otherwise noted.

The kraft lignin was received from eucalyptus (E. urophylla $\times E$. grandis, $24.5 \%$ lignin) cooking by the conventional laboratory-scale kraft method. The kraft pulping was performed in a stainless steel batch reactor using $\mathrm{NaOH}, \mathrm{Na}_{2} \mathrm{~S}$. The parameters used on the cooking and some data on the pulps and black liquors in these cooking series are presented in Table 1. When the target cooking times were reached, black liquors were collected from the reaction vessel. Next DTPA (diethylene triamine pentacetate acid) was slowly added with agitation to black liquor to facilitate metal-ion removal followed by the addition of $2 \mathrm{M}$ sulfuric acid until a $\mathrm{pH}$ of between 2 and 3 was reached causing some of the lignin to precipitate. The solution and resulting precipitate was kept at $0^{\circ} \mathrm{C}$ overnight and thawed at room temperature. The precipitate was separated by centrifugation, then freeze dried and kept frozen until purification. The initial sample was heated in $80 \%$ dioxane containing $0.05 \mathrm{M} \mathrm{HCl}$ at reflux for 2 hours in a nitrogen atmosphere, filtered through a medium sintered glass funnel at $0^{\circ} \mathrm{C}$, and sequentially washed up with $80 \%$ dioxane. All filtrates were collected, neutralized with solid $\mathrm{NaHCO}_{3}$, and then evaporated under reduced pressure $\left(0.02 \mathrm{MPa}, 40^{\circ} \mathrm{C}\right)$. The liquid after rotary evaporation was slowly added to the acidic distilled water ( $\mathrm{pH} 2)$, lignin precipitate was centrifuged and freeze-dried. The lignin sample obtained was washed with methylene chloride $(3 \times 150 \mathrm{~mL})$ and dried under vacuum with phosphorus pentoxide to give pure kraft lignin. The kraft lignin sample designated as EKL was stored in the refrigerator for testing.

\section{Hydrothermal treatment of kraft lignin}

The experiments were performed in a $250 \mathrm{~mL}$ SLM microreactor (Shanghai Laboratory Instrument Works Co., Ltd., China) equipped with a magnetic stirrer and a SLM temperature controller. The scheme of hydrothermal treatment of kraft lignins is given in Figure 1. Typically, $5.0 \mathrm{~g}$ of kraft lignin and $30 \mathrm{~mL}$ of DI water were transferred into the reactor. The system was vented with nitrogen three times before each experiment to remove air from the reactor. For each experiment the reactor was heated in $30 \mathrm{~min}$ from ambient to a working temperature of $130^{\circ} \mathrm{C}$ or $180^{\circ} \mathrm{C}$ or $230^{\circ} \mathrm{C}$, after which the experiment was continued for $15 \mathrm{~min}$ or $60 \mathrm{~min}$. The accuracy of the temperature controller was set at $\pm 1^{\circ} \mathrm{C}$. The content was stirred continuously at $100 \mathrm{rpm}$ during the hydrothermal treatment. At the end of the experiment, the gas was removed from the reactor after the autoclave was cooled down to room temperature with water. Thereafter, the content was taken and the reactor was thoroughly rinsed with DI water. The content was adjusted to $\mathrm{pH} 1-2$ with $1.7 \mathrm{M} \mathrm{HCl}$, filtered using a folded filter paper and washed with DI water of $100 \mathrm{~mL}$. The liquid was extracted using equal amount of diethyl ether, ethyl acetate. The organic phase was separated, dried with anhydrous sodium sulfate, filtered and finally vacuum-dried to obtained oil1 (diethyl ether) and oil2 (ethyl acetate). The residual kraft lignin obtained after filtering and washing was vacuum-dried. Each individual experiment was carried at least three times.

The conversion and yield of various product were calculated on a dry basis using the following equation:

$$
\begin{aligned}
& \text { Conversion }(\mathrm{w} \%)=\frac{m_{\text {kraftlignin }}-m_{\text {residue }}}{m_{\text {kraftlignin }}} \times 100 \\
& \text { Oil yield }(\mathrm{wt} \%)=\frac{m_{\text {oil }}}{m_{\text {kraftlignin }}} \times 100 \\
& \text { Gas yield }(\mathrm{wt} \%)=\frac{m_{(\text {kraftlignin }+ \text { water })}-m_{r}}{m_{(\text {kraftlignin }+ \text { water })}} \times 100 \\
& \text { Residue yield }(\mathrm{wt} \%)=\frac{m_{\text {residue }}}{m_{\text {kraftlignin }}} \times 100 \\
& \text { Other }(\mathrm{wt} \%)=100-(\text { oil1 }+ \text { oil } 2+\text { residue }+ \text { gas })
\end{aligned}
$$

where $m_{\text {kraft lignin }}=$ mass of kraft lignin, $m_{\text {residue }}=$ mass of residual kraft lignin, $m_{\text {oil }}=$ mass of oil, $m_{(\text {kraft }+ \text { water })}=$ charged mass of kraft lignin and water, $m_{r}=$ recovered mass of products, and other $=100-($ mass of oil $1+$ mass of oil + mass of residual kraft lignin + mass of gas).

\section{Chemical analyses}

The acid insoluble (klason lignin) and soluble lignin of kraft lignin were determined by the klason hydrolysis as described by Crawford and Pometto ${ }^{16}$. Five millilitres

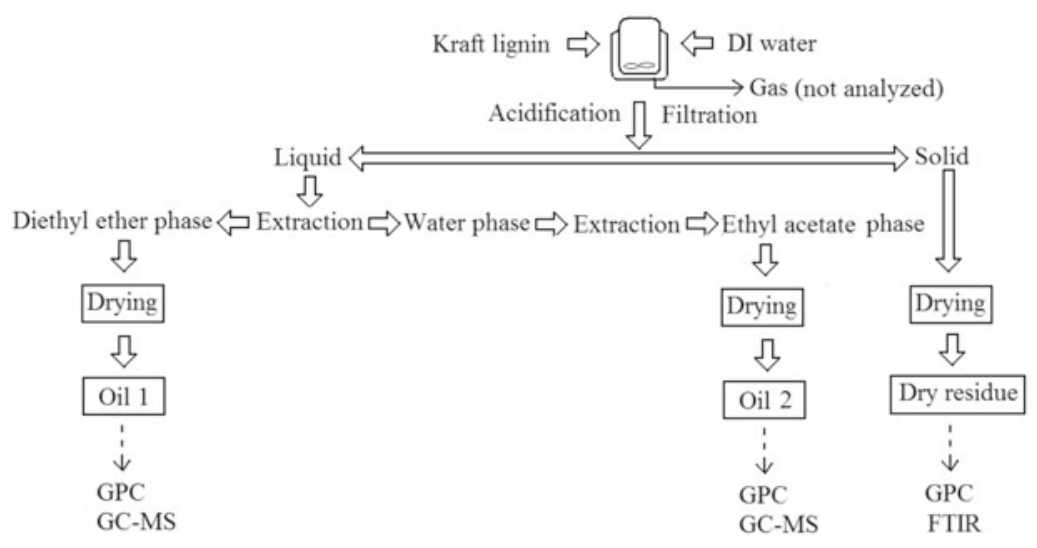

Figure 1. Scheme of hydrothermal treatment of kraft lignin

Table 1. Cooking conditions

\begin{tabular}{|l|c|c|c|c|c|c|c|}
\hline $\begin{array}{c}\text { EA } \\
{[\%]}\end{array}$ & Sulfidity & $\begin{array}{c}\text { Liquor-to } \\
\text {-feedstock ratio } \\
{[\mathrm{L} / \mathrm{kg}]}\end{array}$ & $\begin{array}{c}\text { Max. temp. } \\
{[\mathrm{C}]}\end{array}$ & $\begin{array}{c}\text { Time to max. temp } \\
{[\mathrm{min}]}\end{array}$ & $\begin{array}{c}\text { Time at max. temp. } \\
{[\mathrm{min}]}\end{array}$ & $\begin{array}{c}\text { Kappa number of } \\
\mathrm{pulp}\end{array}$ & $\begin{array}{c}\text { REA of black } \\
\text { liquor } \\
/ \mathrm{gNaOH} \cdot \mathrm{L}^{-1}\end{array}$ \\
\hline 17 & 25 & 4.0 & 165 & 120 & 90 & 17.3 \\
\hline
\end{tabular}

Note: alkali charge on o.d. feedstock wood as $\mathrm{Na}_{2} \mathrm{O}$; EA: effective alkali; $\mathrm{REA}$ : residual effective alkali. 
of the same filtrate obtained was used to determine the carbohydrate content $(0.81 \%)$ by applying Shimadzu UV-vis 160 spectrophotometer at $500 \mathrm{~nm}$ using 10-1000 $\mathrm{g} / \mathrm{mL}$ glucose as standard ${ }^{\mathbf{1 6}}$. The purity of kraft lignin (98\%) was calculated from the sum of acid insoluble and soluble lignin results.

The ash content of kraft lignin $(0.84 \%)$ was measured by the weight difference when kraft lignin was totally burned in muffle at a temperature of $575^{\circ} \mathrm{C}$ in air.

The energy content of the kraft lignin $(24.67 \mathrm{~kJ} / \mathrm{g})$ was analyzed using a KSLR-400C calorimeter.

Molecular weight of samples was determined with Waters 2695 GPC gel permeation chromatography equipped with a differential refractive index detector using tetrahydrofuran (THF) as the eluent $(1.00 \mathrm{~mL} / \mathrm{min})$.

The elemental content of kraft lignin $(56.38 \% \mathrm{C} ; 6.49 \%$ $\mathrm{H} ; 1.32 \% \mathrm{~N} ; 36.81 \% \mathrm{O}$ ) was determined using a Vario EL III elemental analyzer.

\section{FTIR measurements}

FTIR spectral measurements were done with a Bruker Tensor 27 spectrophotometer in the 4000 to $400 \mathrm{~cm}^{-1}$ wavenumber range at a resolution of $2 \mathrm{~cm}^{-1}$ wavelength, by averaging 20 scans.

\section{GC-MS analysis of oils}

The chemical composition of oil including oil1, oil2 obtained from hydrothermal liquefaction of kraft lignin was analyzed by gas chromatograph equipped with a mass selective detector (Agilent HP6890-5973 GC-MS; quartz capillary column, $30 \mathrm{~m} \times 0.25 \mathrm{~mm} \times 0.25 \mu \mathrm{m})$. Temperature program: $40^{\circ} \mathrm{C}$ (hold $10 \mathrm{~min}$ ) $\rightarrow 280^{\circ} \mathrm{C}$ (rate $10^{\circ} \mathrm{C} / \mathrm{min}$ ) hold for $5 \mathrm{~min}$. Compounds were identified by means of the Wiley library-HP G1035A and NIST library of mass spectra and subsets-HP G1033A.

\section{RESULTS AND DISCUSSION}

\section{Oil yields}

A series of hydrothermal experiments were carried out to determine the effects of the temperature and time on the treatment of kraft lignin. In experiments, the reaction temperature at $130,180,230^{\circ} \mathrm{C}$ was used while the reaction time was kept at 15, $60 \mathrm{~min}$. The variations in conversion and yield are presented in Table 2.

It is observed as shown in Table 2 that conversion of kraft lignin was from 25.62 to $19.64 \mathrm{wt} \%$, total oil yield followed a decreasing trend with the increasing temperature and time. The tendencies found are consistent with some studies that carried out hydrothermal treatments with different biomass materials ${ }^{17-19}$. Total oil yields were in the range of 9.74-7.16 wt\% which are considered to be quite acceptable because of the relatively low temperatu- re and short time used in the process. Murnieks et al. ${ }^{6}$ found total oil yield was $7.5 \mathrm{wt} \%$ in ethanol or $2.3 \mathrm{wt} \%$ in toluene in hydrothermal treatment of wheat straw at a temperature of $300^{\circ} \mathrm{C}$ for $4 \mathrm{~h}$; Karagö $\mathrm{z}^{17}$ found total oil yield was from 3.7 to $8.5 \mathrm{wt} \%$ in hydrothermal treatment of sawdust performed at various temperatures of 180, 250, and $280^{\circ} \mathrm{C}$ for $15 \mathrm{~min}$ and $60 \mathrm{~min}$. Under the operating conditions in this study, the temperature appears to have a stronger effect on total oil yield than the reaction time. Further increase in temperature at $180^{\circ} \mathrm{C}(15 \mathrm{~min}, 60 \mathrm{~min})$ led to a sharp effect, as the reaction temperature increased from $180(15 \mathrm{~min}, 60 \mathrm{~min})$ to $230^{\circ} \mathrm{C}(15 \mathrm{~min}, 60 \mathrm{~min})$ total oil yield decreased from $(9.22,8.58)$ to $(7.44,7.16)$ wt $\%$. Therefore, $130^{\circ} \mathrm{C}$ for $15,60 \mathrm{~min}$ would be desirable reaction temperature for hydrothermal depolymerization of kraft lignin. The results suggest that decomposition of kraft lignin and/or secondary decomposition of oil to gas with increasing temperature and time occur as evidenced by the fact that the gas yield increased from $(6.30,7.38)$ to $(8.53,9.74)$ to $(11.27,17.70) \mathrm{wt} \%$.

The yields of water-soluble hydrocarbons in hydrothermal treatment of kraft lignin (others in Table 2) were very low, which may be caused by the low content of carbohydrate in kraft lignin $(0.81 \mathrm{wt} \%)^{\mathbf{2 0}}$.

\section{GC-MS analysis of oils}

The obtained oils were analyzed using GC-MS, and the results for two oils are given in Table 3. The compounds produced from thermal degradation of kraft lignin were classified to two types: G-type (compounds derived from guaiacyl-propane, including vanillin, 1,2-benzenediol, 4-hydroxy-3-methoxyphenyl ethanone, guaiacol, 4-hydroxy-3-methoxyphenyl propanone, 4-hydroxy-3-methoxy benzeneacetic acid) and S-type (compounds derived from syringyl-propane, including 2,6-dimethoxy phenol, 4-hydroxy-3,5-dimethoxy benzaldehyde, 4-hydroxy-3,5-dimethoxyphenyl ethanone). The main products from the hydrothermal conversion of kraft lignin were phenolic compounds produced by hydrolysis of ether-bonds in kraft lignin during hydrothermal treatment ${ }^{21}$. In both oils the main compound was guaiacol (2-methoxy phenol), and the total amount of the guaiacol (2-methoxy phenol) was in the range of $12-55 \%$ of oil depending on different reaction conditions. The maximum amount of guaiacol (55\% of oil) was obtained at $130^{\circ} \mathrm{C} / 60$ min which is a low temperature and short time. Here, attentions are focused on the differences between oil1 and oil2. The oil1 consisted mostly of guaiacol, 4-hydroxy-3,5-dimethoxy benzaldehyde, 4-hydroxy-3,5-dimethoxyphenyl ethanone, hexanedioic acid, and the compounds which were not observed in oil2, 2,6-dimethoxy phenol, vanillin, 1,2-benzenediol, 4-hydroxy-3-methoxy phenyl ethanone, 4-hydroxy-3-methoxy phenyl propanone, 4-hydroxy-3-methoxy benzeneacetic acid. According to the study

Table 2. Yield of various products for hydrothermal treatment of kraft lignin (standard deviations on conversion products: $\pm 0.5 \%$ )

\begin{tabular}{|c|c|c|c|c|c|c|c|}
\hline \multirow[b]{2}{*}{ Temperature/Time } & \multirow[b]{2}{*}{ Conversion (wt \%) } & \multicolumn{3}{|c|}{ Oil } & \multirow[b]{2}{*}{$\begin{array}{c}\text { Gas } \\
{[w t \%]}\end{array}$} & \multirow[b]{2}{*}{$\begin{array}{l}\text { Residue } \\
\text { [wt\%] }\end{array}$} & \multirow[b]{2}{*}{$\begin{array}{l}\text { Others } \\
\text { [wt\%] }\end{array}$} \\
\hline & & $\begin{array}{c}\text { Oil1 } \\
\text { [wt\%] }\end{array}$ & $\begin{array}{c}\text { Oil2 } \\
{[w t \%]}\end{array}$ & $\begin{array}{l}\text { total oil } \\
\text { [wt\%] }\end{array}$ & & & \\
\hline $130^{\circ} \mathrm{C} / 15 \mathrm{~min}$ & 22.34 & 0.96 & 8.78 & 9.74 & 6.30 & 77.66 & 6.30 \\
\hline $130^{\circ} \mathrm{C} / 60 \mathrm{~min}$ & 19.64 & 1.10 & 7.92 & 9.02 & 7.38 & 80.36 & 3.24 \\
\hline $180^{\circ} \mathrm{C} / 15 \mathrm{~min}$ & 20.72 & 1.66 & 7.56 & 9.22 & 8.53 & 79.28 & 2.97 \\
\hline $180^{\circ} \mathrm{C} / 60 \mathrm{~min}$ & 20.64 & 1.78 & 6.80 & 8.58 & 9.74 & 79.36 & 2.32 \\
\hline $230^{\circ} \mathrm{C} / 15 \mathrm{~min}$ & 23.38 & 2.10 & 5.34 & 7.44 & 11.27 & 76.62 & 4.67 \\
\hline $230^{\circ} \mathrm{C} / 60 \mathrm{~min}$ & 25.62 & 2.32 & 4.84 & 7.16 & 17.70 & 74.38 & 0.76 \\
\hline
\end{tabular}


Table 3. Composition of oils by GC-MS Analysis

\begin{tabular}{|c|c|c|c|c|c|c|c|}
\hline \multirow{3}{*}{ RT } & \multirow{3}{*}{$\begin{array}{l}\text { Name of } \\
\text { compound }\end{array}$} & \multicolumn{6}{|c|}{ Oil1/Oil2/Total [\%] } \\
\hline & & \multicolumn{2}{|c|}{$130^{\circ} \mathrm{C}$} & \multicolumn{2}{|c|}{$180^{\circ} \mathrm{C}$} & \multicolumn{2}{|c|}{$230^{\circ} \mathrm{C}$} \\
\hline & & $15 \mathrm{~min}$ & $60 \mathrm{~min}$ & $15 \mathrm{~min}$ & $60 \min$ & $15 \mathrm{~min}$ & $60 \mathrm{~min}$ \\
\hline 16.819 & $\begin{array}{l}\text { 2,6-Dimethoxy } \\
\text { phenol }\end{array}$ & $7.35 /-/ 7.35$ & $2.85 /-/ 2.85$ & $6.61 /-/ 6.61$ & $8.14 /-/ 8.14$ & 11.92/-/11.92 & $14.50 /-/ 14.50$ \\
\hline 17.523 & Vanillin & $4.08 /-/ 4.08$ & $1.44 /-/ 1.44$ & $3.02 /-/ 3.02$ & $3.39 /-/ 3.39$ & $3.47 /-/ 3.47$ & $2.96 /-/ 2.96$ \\
\hline 17.872 & 1,2-benzenediol & $2.89 /-/ 2.89$ & $3.59 /-/ 3.59$ & $3.55 /-/ 3.55$ & $2.56 /-/ 2.56$ & $1.49 /-/ 1.49$ & $2.29 /-/ 2.29$ \\
\hline 18.656 & $\begin{array}{l}\text { 4-Hydroxy-3- } \\
\text {-methoxyphenyl } \\
\text { ethanone }\end{array}$ & $4.75 /-/ 4.75$ & $1.66 /-/ 1.66$ & $3.85 /-/ 3.85$ & $3.75 /-/ 3.75$ & $3.94 /-/ 3.94$ & $4.29 /-/ 4.29$ \\
\hline 18.892 & $\begin{array}{c}\text { Guaiacol (2- } \\
\text {-Methoxy phenol) }\end{array}$ & $9.15 / 2.84 / 11.99$ & $51.10 / 3.55 / 54.65$ & $11.76 / 2.38 / 14.14$ & $39.41 / 3.36 / 42.77$ & $18.05 / 6.42 / 24.47$ & $20.37 / 4.00 / 24.37$ \\
\hline 19.139 & $\begin{array}{l}\text { 4-Hydroxy-3- } \\
\text {-methoxyphenyl } \\
\text { propanone }\end{array}$ & $-/-/-$ & $-/-/-$ & $2.20 /-/ 2.20$ & $2.77 /-/ 2.77$ & $4.01 /-/ 4.01$ & $5.64 /-/ 5.64$ \\
\hline 20.583 & $\begin{array}{c}\text { 4-Hydroxy-3- } \\
\text {-methoxy } \\
\text { benzeneacetic } \\
\text { acid }\end{array}$ & $-/-/-$ & $-/-/-$ & $1.52 /-/ 1.52$ & $1.42 /-/ 1.42$ & $1.99 /-/ 1.99$ & $1.87 /-/ 1.87$ \\
\hline 20.750 & $\begin{array}{c}\text { 4-hydroxy-3,5- } \\
\text {-dimethoxy } \\
\text { benzaldehyde }\end{array}$ & $14.48 / 0.27 / 14.75$ & $5.82 / 0.28 / 6.10$ & $10.10 / 0.63 / 10.73$ & $9.96 / 0.55 / 10.51$ & $9.38 / 1.03 / 10.41$ & 7.23/1.16/8.39 \\
\hline 21.577 & $\begin{array}{l}\text { 4-Hydroxy-3,5- } \\
\text {-dimethoxyphenyl } \\
\text { ethanone }\end{array}$ & $17.41 / 0.66 / 18.07$ & $8.06 / 0.70 / 8.76$ & $14.64 / 1.23 / 15.87$ & $13.06 / 1.81 / 14.87$ & $12.18 / 1.76 / 13.94$ & $11.87 / 2.31 / 14.18$ \\
\hline 27.742 & $\begin{array}{c}\text { Hexanedioic } \\
\text { acid }\end{array}$ & $-/ 8.80 / 8.80$ & $-/ 9.16 / 9.16$ & $-/ 9.81 / 9.81$ & $-/ 8.61 / 8.61$ & $-/ 7.90 / 7.90$ & $-/ 7.83 / 7.83$ \\
\hline
\end{tabular}

on lignin model compounds, guaiacol was decomposed to form 1,2-benzenediol in oil1 ${ }^{22}$.

\section{Molecular weight of oils}

Molecular weight of oils was analyzed by GPC (Table 4). The $\mathrm{M}_{\mathrm{w}}$ of oils decreased with the temperature and time. The highest value was 534 obtained at $130^{\circ} \mathrm{C} / 15$ min in oil1, which was about $72 \%$ increases compared with the lowest value (310) obtained at $230^{\circ} \mathrm{C} / 60 \mathrm{~min}$ in oil2. This may be explained by the hydrothermal reaction at higher temperature and longer time which resulted in depolymerization occurred in oils ${ }^{23}$.

\section{Structural changes of kraft lignin}

In order to further understand the conversion mechanism of kraft lignin under hydrothermal conditions, the changes in the chemical structure of the kraft lignin depending on the temperature and time were analyzed with FTIR (Fig. 2) ${ }^{24}$. As temperature and time was increased, the strength of phenolic $\mathrm{OH}$ group $\left(1326 \mathrm{~cm}^{-1}\right)$ began to strengthen by the reaction of $\mathrm{O}_{-} \mathrm{CH}_{3}(2940,2886,1458$ $\left.\mathrm{cm}^{-1}\right)$ homolysis and $\beta-\mathrm{O}-4\left(1114 \mathrm{~cm}^{-1}\right)$ degradation ${ }^{25}$. This can be confirmed by the high concentration of phenols (Table 3) generated during hydrothermal treatment. However, when the temperature and time was increased, the strength of these peaks at 1714 (carbonyl groups), $1510 \mathrm{~cm}^{-1}$ (aromatic rings) was decreased. This was confirmed by the existence of carbonyl-compounds and hexanedioic acid as shown in Table 3.

\section{CONCLUSION}

During hydrothermal treatment of kraft lignin in water, reaction conditions had remarkable effects on yield and composition, as well as molecular weight of oils. Higher reaction temperature or longer residence time decreased total oil yield. The maximum of total oil yield (10\% of kraft lignin) was obtained at $130^{\circ} \mathrm{C} / 15 \mathrm{~min}$. The obtained oil products were mainly phenolics. The highest guaiacol amount (55\% of oil) was achieved at $130^{\circ} \mathrm{C} / 60$ min. The decreased amount of $\beta$-O-4 linkages, carbonyl groups, aromatic rings and increased amount of phenolic $\mathrm{OH}$ groups in kraft lignin by FTIR analysis favored the conversion of kraft lignin.

\section{ACKNOWLEDGEMENT}

This work was supported by the National Natural Science Foundation of P. R. China (21166011), the Open Research Foundation of Guangxi Key Laboratory of Petrochemical Resource Processing and Process Intensification Technology of Guangxi University (2014K002), the Open Research Foundation of Key Laboratory of Green Chemistry of Sichuan Institutes of Higher Education of Sichuan University of Science and Engineering (LYJ1406), the Open Research Foundation of Jiangsu Provincial Key Laboratory of Pulp and Paper Science and Technology of Nanjing Forestry University (201320), the Open Research Foundation of Jiangsu Key Laboratory for Biomass-based Energy and Enzyme Technology of Huaiyin Normal University (JSBEET1318), the Open

Table 4. Molecular weight and polydispersity of oils

\begin{tabular}{|l|c|c|c|c|}
\hline & & & Oil 2 & \\
\cline { 2 - 5 } & $\mathrm{M}_{\mathrm{w}}{ }^{1}$ & $\mathrm{PD}^{2}$ & $\mathrm{M}_{\mathrm{w}}$ & $\mathrm{PD}$ \\
\hline Kraft lignin & 3031 & 1.6 & 416 & - \\
\hline $130^{\circ} \mathrm{C} / 15 \mathrm{~min}$ & 534 & 1.08 & 396 & 1.14 \\
\hline $130^{\circ} \mathrm{C} / 60 \mathrm{~min}$ & 473 & 1.09 & 384 & 1.16 \\
\hline $180^{\circ} \mathrm{C} / 15 \mathrm{~min}$ & 460 & 1.08 & 367 & 1.17 \\
\hline $180^{\circ} \mathrm{C} / 60 \mathrm{~min}$ & 434 & 1.07 & 328 & 1.16 \\
\hline $230^{\circ} \mathrm{C} / 15 \mathrm{~min}$ & 413 & 1.05 & 310 & 1.14 \\
\hline $230^{\circ} \mathrm{C} / 60 \mathrm{~min}$ & 407 & 1.05 & & 1.11 \\
\hline
\end{tabular}

${ }^{1}$ weight average molecular weight; ${ }^{2}$ polydispersity. 


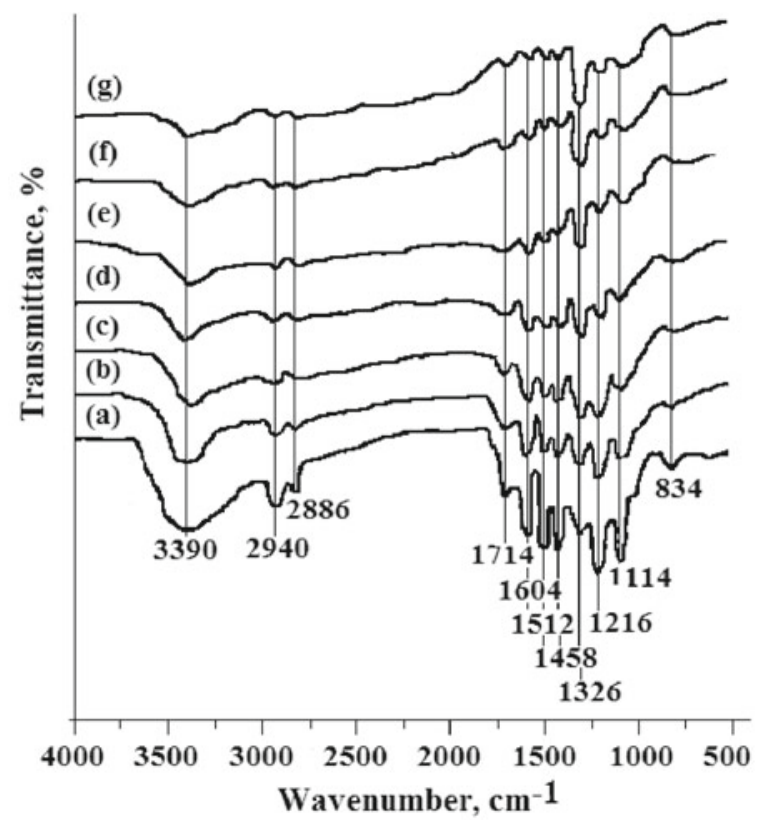

Figure 2. FTIR of kraft lignin and residual kraft lignin. (a) EKL; (b) residue at $130^{\circ} \mathrm{C} / 15 \mathrm{~min}$; (c) residue at $130^{\circ} \mathrm{C} / 60 \mathrm{~min}$; (d) residue at $180^{\circ} \mathrm{C} / 15 \mathrm{~min}$; (e) residue at $180^{\circ} \mathrm{C} / 60 \mathrm{~min}$; (f) residue at $230^{\circ} \mathrm{C} / 15$ $\mathrm{min} ;(\mathrm{g})$ residue at $230^{\circ} \mathrm{C} / 60 \mathrm{~min}$

Research Foundation of Tianjin Key Laboratory of Pulp and Paper of Tianjin University of Science and Technology (201314) and the Open Research Foundation of State Key Laboratory of New Ceramics and Fine Processing of Tsinghua University (KF201402).

\section{LITERATURE CITED}

1. Du, X., Gellerstedt, G. \& Li, J. (2013). Universal fractionation of lignin-carbohydrate complexes (LCCs) from lignocellulosic biomass: an example using spruce wood. The Plant J. 74, 328-338. DOI: 10.1111/tpj.12124.

2. Calvo-Flores, F.G. \& Dobado, J.A. (2010). Lignin as renewable raw material. ChemSusChem 3, 1227-1235. DOI: 10.1002/CSSC.201000157.

3. Zhou, X.-F. (2014). Selective oxidation of kraft lignin over zeolite-encapsulated $\mathrm{Co}(\mathrm{II})\left[\mathrm{H}_{4}\right]$ salen and $\left[\mathrm{H}_{2}\right]$ salen complexes. J. Appl. Polym. Sci. 131, 9594-9602. DOI: 10.1002/app.40809.

4. Joffres, B., Laurenti, D., Charon, N., Daudin, A., Quignard, A. \& Geantet, C. (2013). Thermochemical conversion of lignin for fuels and chemicals: A review. Oil Gas Sci. Technol. 68, 753-763. DOI: 10.2516/ogst/2013132.

5. Babu, B.V. (2008). Biomass pyrolysis: a state-of-the-art review. Biofuels Bioprod. Bior. 2, 393-414. DOI: 10.1002/bbb.92.

6. Murnieks, R., Kampars, V., Malins, K. \& Apseniece, L. (2014). Hydrotreating of wheat straw in toluene and ethanol. Bioresour. Technol. 163, 106-111. DOI: 10.1016/j. biortech.2014.04.022.

7. Pinkowska, H., Wolak, P. \& Zocinska, A. (2012). Hydrothermal decomposition of alkali lignin in sub- and supercritical water. Chem. Eng. J. 187, 410-414. DOI: 10.1016/J. CEJ.2012.01.092.

8. Horacek, J., Homola, F., Kubickova, I. \& Kubicka, D. (2012). Lignin to liquids over sulfided catalysts. Catal. Today 179, 191-198. DOI: 10.1016/j.cattod.2011.06.031.

9. Chimentao, R.J., Lorente, E., Gispert-Guirado, F., Medina, F. \& Lopez, F. (2014). Hydrolysis of dilute acid-pretreated cellulose under mild hydrothermal conditions. Carbohyd. Polym. 111, 116-124. DOI: 10.1016/J.CARBPOL.2014.04.001.
10. Demirbas, A. (2009). Biorefineries: current activities and future developments. Energy Convers. Manage. 50, 2782-2801. DOI: 10.1016/j.enconman.2009.06.035.

11. Mafakheri, F. \& Nasiri, F. (2014). Modeling of biomass-to-energy supply chain operations: Applications, challenges and research directions. Energ. Policy 67, 116-126. DOI: 10.1016/J. ENPOL.2013.11.071.

12. Kang, S., Li, X., Fan, J. \& Chang, J. (2013). Hydrothermal conversion of lignin: A review. Renew. Sust. Energ. Rev. 27, 546-558. DOI: 10.1016/J.RSER.2013.07.013.

13. Kumar, S. \& Gupta, R.B. (2009). Biocrude production from switch grass using subcritical water. Energ. Fuels 23, 5151-5159. DOI: 10.1021/ef900379p.

14. dos Santos, P.S.B., Erdocia, X., Gatto, D.A. \& Labidi, J. (2014). Characterisation of kraft lignin separated by gradient acid precipitation. Ind. Crops Prod. 55, 149-154. DOI: 10.1016/J. indcrop.2014.01.023.

15. Jansson, Z.L. \& Brannvall, E. (2014). Effect of kraft cooking conditions on the chemical composition of the surface and bulk of spruce fibers. J. Wood Chem. Technol. 34, 291-300. DOI: $10.1080 / 02773813.2013 .872661$.

16. Crawford, R.L. \& Pometto, A.L. (1988). Methods in enzymology. San Diego: Academic Press Inc.

17. Karagöz, S., Bhaskar, T., Muto, A., Sakata, Y. \& Uddin, Md.A. (2004). Low-temperature hydrothermal treatment of biomass: effect of reaction parameters on products and boiling point distributions. Energ. Fuel. 18, 234-241. DOI: 10.1021/ ef030133g.

18. Ye, Y., Fan, J. \& Chang, J. (2012). Effect of reaction conditions on hydrothermal degradation of cornstalk lignin. $J$. Anal. Appl. Pyrol. 94, 190-195. DOI: 10.1016/J.JAAP.2011.12.005.

19. Pala, M., Kantarli, I.C., Buyukisik, H.B. \& Yanik, J. (2014). Hydrothermal carbonization and torrefaction of grape pomace: A comparative evaluation. Bioresour. Technol. 161, 255-262. DOI: 10.1016/J.BIORTECH.2014.03.052.

20. Sakaki, T., Shibata, M., Miki, T., Hirosue, H. \& Hayashi, N. (1996). Decomposition of cellulose in near-critical water and fermentabality of the product. Energ. Fuel. 10, 684-688.

21. Wahyudiono, Sasaki, M. \& Goto, M. (2009). Conversion of biomass model compound under hydrothermal conditions using batch reactor. Fuel 88, 1656-1664. DOI: 10.1016/J. FUEL.2009.02.028.

22. Wahyudiono, Kanetake, T., Sasaki, M. \& Goto, M. (2007). Decomposition of a lignin model compound under hydrothermal conditions. Chem. Eng. Technol. 30, 1113-1122. DOI: $10.1002 /$ ceat.200700066.

23. Toledano, A., Serrano, L. \& Labidi, J. (2014). Improving base catalyzed lignin depolymerization by avoiding lignin repolymerization. Fuel 116, 617-624. DOI: 10.1016/j.fuel.2013.08.071.

24. Nada, A.M.A., Yousef, M.A., Shaffei, K.A. \& Salah, A.M. (1998). Infrared spectroscopy of some treated lignins. Polym. Degrad. Stabil. 62, 157-163.

25. Kawamoto, H., Ryoritani, M. \& Saka, S. (2008). Different pyrolytic cleavage mechanisms of $\beta$-ether bond depending on the side-chain structure of lignin dimers. J. Anal. Appl. Pyro. 81, 88-94. DOI: 10.1016/J.JAAP.2007.09.006. 